\title{
Predictable Impact of Lighting Control on the Energy Consumption of a Building through Computational Simulation
}

\author{
H. Bernardo ${ }^{1,3}$, S. Leitão ${ }^{2}$, L. Neves ${ }^{1,3}$ and P. Amaral ${ }^{1,3}$ \\ ${ }^{1}$ Department of Electrical Engineering, School of Technology and Management, Polytechnic Institute of Leiria \\ Campus 2 - Morro do Lena - Alto do Vieiro, 2411-901 Leiria, Apartado 4163, Portugal \\ Phone: +351 244820 300, e-mails: hermano.bernardo@estg.ipleiria.pt, lneves@estg.ipleiria.pt, pgata@estg.ipleiria.pt
}

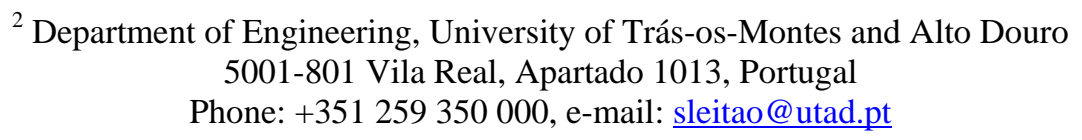

${ }^{3}$ Institute for Systems and Computers Engineering at Coimbra

Rua Antero de Quental, Nº199, 3000 - 033 Coimbra, Portugal

Phone: +351 239851040

\begin{abstract}
Building energy simulation tools provide accurate predictions of the energetic performance of buildings and thermal comfort of its occupants, allowing an evaluation of the impact of proposed improvement measures, in order to support choice for the more economically viable.
\end{abstract}

This paper aims at determining the energy saving potential that can be obtained by adequate measures and investments. It presents the simulated values of the impact on the energy consumptions of a building, caused by artificial lighting control systems set to maximize use of natural lighting.

Results show that optimization measures have a significant impact on energy consumptions reduction, and lead to important economical savings.

\section{Key words}

Energy efficiency in buildings, energy simulation tools, lighting.

\section{Introduction}

Lighting systems are responsible for about $10 \%$ to $20 \%$ of all electricity consumption in industrialized countries, and therefore should be primary targets of energy consumption rationalization measures [1].

In buildings, particularly, lighting consumptions can represent up to $30 \%$ of total consumed energy, which is decisive in tertiary sector buildings, such as commercial buildings and other similar buildings.
The optimization of lighting systems integration can lead to an increase in illuminance levels and substantial savings on the electricity bill. An efficient lighting system is thus obtained when the integration of natural lighting and artificial lighting is optimized.

Energy simulation tools allow researchers to evaluate, usually on a yearly basis, the energetic performance of a building and its climatization systems.

One of the main advantages of using computational simulation is the possibility to compare different alternatives to the conception or rehabilitation of buildings, and equipments providing lighting, heating/cooling and others, in terms of energy performance and thermal comfort.

Following recent Portuguese normative on energy efficiency in buildings, this work presents a contribution to the identification of alternatives that can minimize energy consumption of services buildings, therefore contributing to improve their energy performance.

\section{Case study}

The building selected as the case study for this work is the Canteen 3, Campus 2 of the Polytechnic Institute of Leiria. It was built in 2005.

The building has a total surface of approximately 1487 $\mathrm{m}^{2}$. It has a rectangular geometry, and is composed of two floors (ground floor and first floor), each 3,2 metres high. The meals hall, the kitchen and logistic support areas are located on the ground floor. On the first floor 
there is a restaurant a la carte, a cafeteria and other logistic areas.

The main façade of the building faces, predominantly, South-East.

\section{Methodology}

The basis for the following work was a computational model of the building (Fig. 1), created using the DesignBuilder software, and adequately calibrated and validated using field measurements. In the process of creating and adjusting such a model, the building envelope, the climatization system, the distribution of internal loads and the usage profiles were considered, and a simulation of the actual lighting system installed presently was performed. Due to the high potential of natural lighting usage during sunlight hours, other simulations considered the use of lighting sensors associated with dimmers, in order to adjust artificial lighting according to the natural lighting available at each moment. This would be implemented in some areas of the building, such as the meals hall, the cafeteria and the restaurant.

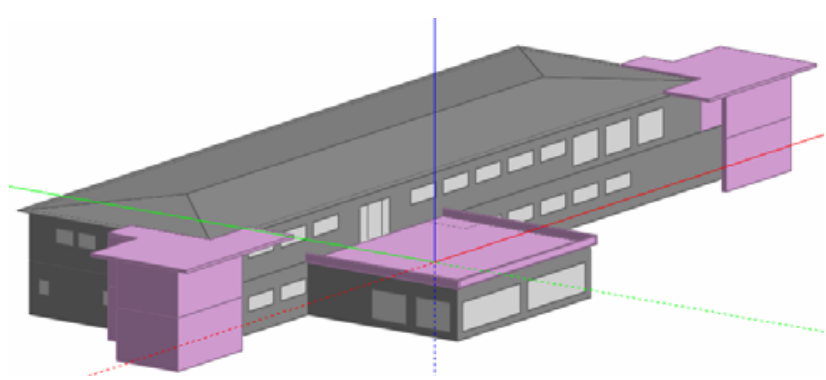

Fig. 1. A view of the computational simulation model of the case study building.

In order to characterize the building's lighting system, a survey of the number of luminaries and lamps, their control systems, the technology used and the lighting level of each room was performed. The survey was performed as an energy audit, also aiming to evaluate existing lighting systems efficiency and detect possible improvements, both towards lower energy consumption and improvement on visual comfort to the users.

An approximate total of $14,3 \mathrm{~kW}$ of electric power for lighting is installed in the building, mainly divided by four types of lamp. Tubular fluorescent T5-type lamps are predominant, representing $47,5 \%$ of installed power. Also tubular fluorescent lamps, T8-type, represent 23,9\%; compact fluorescent lamps amount to $19 \%$; and high-pressure sodium vapor lamps amount to $9,1 \%$.

The conversion factors to primary energy used are the following, according to Portuguese norm RCCTE [4]: 0,290 kgoe/kWh for electricity and 0,086 kgoe $/ \mathrm{kWh}$ for natural gas, parameters defined due to the energy mix of the country.
In order to evaluate greenhouse gases emissions and carbon intensity $\left(\mathrm{kgCO}_{2} \mathrm{e}\right)$, an emission factor of 0,47 $\mathrm{kgCO}_{2} \mathrm{e} / \mathrm{kWh}$ was used for electricity and 2.683,7 $\mathrm{kgCO}_{2} \mathrm{e} /$ toe, according to the Portuguese norm “Despacho n 17313/2008”, June 26, 2008.

\section{A. Case study simulation}

The annual energy consumptions, as obtained through simulation of the building model, applying reference patterns set by Portuguese norm RSECE [5], are presented in Table I:

TABLE I. - Energy consumption - reference model.

\begin{tabular}{|c|c|c|c|}
\hline Energy usage & $\begin{array}{c}\text { Electricity } \\
{[\mathrm{kWh}]}\end{array}$ & $\begin{array}{c}\text { Thermal } \\
\text { energy }[\mathrm{kWh}]\end{array}$ & $\begin{array}{c}\text { TOTAL } \\
{[\mathrm{kgoe}]}\end{array}$ \\
\hline Lighting & 68.106 & 0 & 19.751 \\
\hline Equipments & 214.881 & 156.076 & 75.738 \\
\hline Heating & 0 & 409.504 & 35.217 \\
\hline Cooling & 69.236 & 0 & 20.078 \\
\hline Others & 6.888 & 180.402 & 17.512 \\
\hline TOTAL & 359.111 & 745.982 & 168.296 \\
\hline
\end{tabular}

Looking at Table I, it is patent that, under these conditions, the building has a total primary energy consumption of 168.296 kgoe.

The chart in Fig. 2 shows the disaggregation of annual total primary energy consumptions by final use.

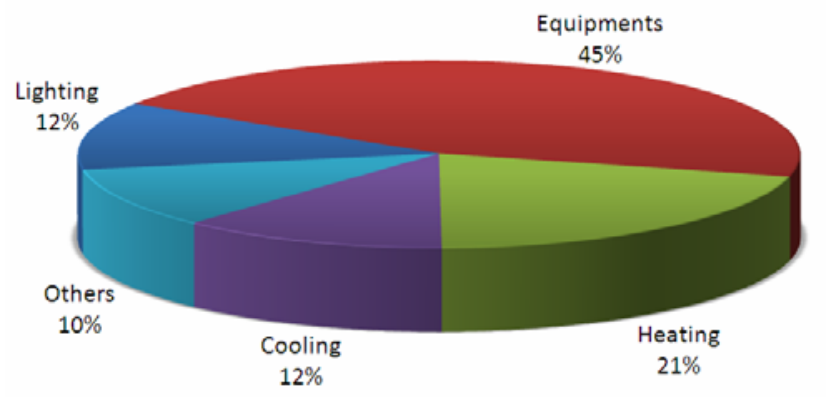

Fig. 2. Energy consumptions disaggregation - reference model.

B. Simulation of the case study with lighting systems control.

The annual energy consumptions, as obtained through simulation of the building model with lighting systems control, applying reference patterns set by Portuguese norm RSECE [5], are presented in Table II: 
TABLE II. - Energy consumptions - reference model with lighting systems optimization

\begin{tabular}{|c|c|c|c|}
\hline Energy usage & $\begin{array}{c}\text { Electricity } \\
{[\mathrm{kWh}]}\end{array}$ & $\begin{array}{c}\text { Thermal } \\
\text { Energy }[\mathrm{kWh}]\end{array}$ & $\begin{array}{c}\text { TOTAL } \\
{[\mathrm{kgoe}]}\end{array}$ \\
\hline Lighting & 45.381 & 0 & 13.160 \\
\hline Equipments & 214.881 & 156.076 & 75.738 \\
\hline Heating & 0 & 419.173 & 36.049 \\
\hline Cooling & 68.060 & 0 & 19.737 \\
\hline Others & 6.888 & 180.402 & 17.512 \\
\hline TOTAL & 335.210 & 755.651 & 162.196 \\
\hline
\end{tabular}

Looking at Table II, it is patent that, under these conditions, the building has a total primary energy consumption of 162.196 kgoe.

The chart in Fig. 3 shows the disaggregation of annual total primary energy consumptions by final use.

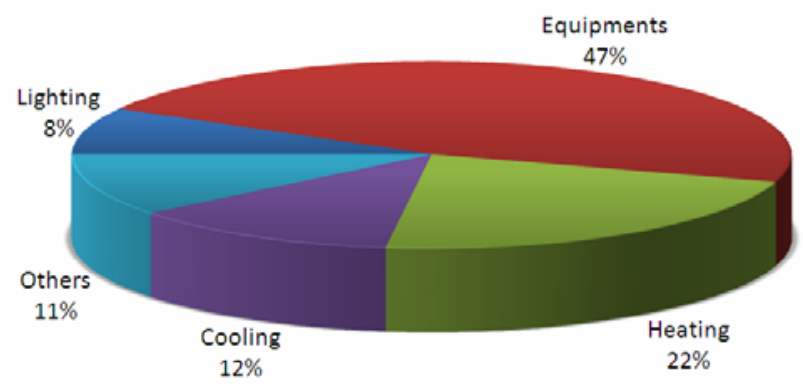

Fig. 3. Energy consumptions disaggregation - reference model with lighting systems optimization.

\section{Comparative analysis of results}

Comparing the results of both simulations performed, using the reference patterns, there are visible differences in the obtained results.

Table III presents a comparison between the standard case, with no optimization system, and the optimized case, with illuminance sensors associated with dimmers.

TABLE III. - Comparison of results - electricity.

\begin{tabular}{|c|c|c|c|}
\hline $\begin{array}{c}\text { Energy } \\
\text { usage }\end{array}$ & $\begin{array}{c}\text { Base case } \\
{[\mathrm{kWh}]}\end{array}$ & $\begin{array}{c}\text { Base case }+ \\
\text { optimization }[\mathrm{kWh}]\end{array}$ & $\begin{array}{c}\text { Reduction } \\
{[\%]}\end{array}$ \\
\hline Lighting & 68.106 & 45.381 & 33,4 \\
\hline Equipments & 214.881 & 214.881 & 0,0 \\
\hline Cooling & 69.236 & 68.060 & 1,7 \\
\hline Others & 6.888 & 6.888 & 0,0 \\
\hline TOTAL & 359.111 & 335.210 & 6,7 \\
\hline
\end{tabular}

It can be seen that there is a reduction of energy consumption, mainly due to the reduction of lighting consumptions, but also due to the cooling systems energy reduction, which is associated with a reduction of the energy bill.

The savings on electricity amount to $6,7 \%$ of total electricity consumption. However, the reduction on artificial lighting systems is quite significant $(33,4 \%)$.

In terms of total primary energy, results obtained are presented on Table IV:

TABLE IV. - Comparison of results - primary energy.

\begin{tabular}{|c|c|c|c|}
\hline Energy usage & $\begin{array}{c}\text { Base case } \\
{[\mathrm{kWh}]}\end{array}$ & $\begin{array}{c}\text { Base case }+ \\
\text { optimization }[\mathrm{kWh}]\end{array}$ & $\begin{array}{c}\text { Reduction } \\
{[\%]}\end{array}$ \\
\hline Lighting & 19.751 & 13.160 & 33,4 \\
\hline Equipments & 75.738 & 75.738 & 0,0 \\
\hline Heating & 35.217 & 36.049 & $-2,4$ \\
\hline Cooling & 20.078 & 19.737 & 1,7 \\
\hline Others & 17.512 & 17.512 & 0,0 \\
\hline TOTAL & 168.296 & 162.196 & 3,6 \\
\hline
\end{tabular}

The energy consumption of the heating systems has a slight increase $(2,4 \%)$ due to the reduction of the thermal load inside the building but, globally, the energy consumption shows a decrease.

It is patent that, despite the significant reduction of energy consumptions of artificial lighting (33,4\%), this represents a sole saving of $3,6 \%$ on the total energy (electrical and thermal) consumption of the building.

\section{Energy saving potential}

From the results stated previously, the energy savings resulting of the optimization of artificial lighting systems, thus maximizing the resource to natural lighting, is presented on Table V:

TABLE V. - Savings potential.

\begin{tabular}{|l|c|c|c|c|}
\hline \multicolumn{1}{|c|}{$\begin{array}{c}\text { Lighting } \\
\text { optimization }\end{array}$} & $\begin{array}{c}\text { Energy } \\
\text { saving } \\
{[\text { kgoe] }}\end{array}$ & $\begin{array}{c}\text { Cost } \\
\text { reduction } \\
{[€]}\end{array}$ & $\begin{array}{c}\text { Investment } \\
{[€]}\end{array}$ & $\begin{array}{c}\text { Return } \\
\text { [years] }\end{array}$ \\
\hline $\begin{array}{l}\text { Repercussion } \\
\text { on electricity } \\
\text { consumption }\end{array}$ & 6.931 & 2.151 & \multirow{2}{*}{3.000} & 1,83 \\
\cline { 1 - 3 } $\begin{array}{l}\text { Repercussion } \\
\text { on natural gas } \\
\text { consumption }\end{array}$ & -831 & -515 & & \\
\cline { 1 - 3 } TOTAL & 6.100 & 1.636 & & \\
\hline
\end{tabular}

Based on obtained results, it is visible that, although there is a reduction of electricity costs of $2.151 €$, the yearly cost of natural gas actually increases by $515 €$, due to the decrease of the thermal load of the building in the heating season.

Globally, there is an energy saving potential of 6.100 kgoe, which means a total cost reduction of $1.636 €$.

Considering the investment cost (3.000€) associated with the installation of the control and optimization system, 
and the cost reduction calculated, the return period of the investment is less than two years.

Implementing this simple yet effective optimization measure would cause a reduction of $\mathrm{CO}_{2}$ emissions of $9.002 \mathrm{kgCO}_{2} \mathrm{e}$, due only to energy savings.

\section{Conclusion}

During the winter, and assuming thermal loads are lower than the losses, artificial lighting systems can be beneficial and should always be taken into account when performing simulations and dimensioning climatization systems, as they represent a thermal load which contributes to the building's heating. During the summer, lighting systems should also be considered, this time because they represent an extra load that must be removed by the cooling system.

It is then clear that implementing artificial lighting management and control systems constitutes an interesting alternative to promote a more efficient use of energy and to improve the energy performance of a building of these characteristics.

\section{Acknowledgement}

The authors would like to acknowledge the facilities provided by ESTG-IPL.

\section{References}

[1] "Eficiência Energética em Edifícios" BCSD Portugal, Lisboa, 2007.(in Portuguese)

[2] Roriz, L., "Climatização - Concepção, Instalação e Condução de Sistemas”, Edições Orion - Portugal (2006). (in Portuguese)

[3] SCE - Sistema Nacional de Certificação Energética e da Qualidade do Ar Interior nos Edifícios, Decreto-Lei n. ${ }^{\circ} 78$, de 4 de Abril de 2006.(in Portuguese)

[4] RCCTE - Regulamento das Características de Comportamento Térmico dos Edifícios, Decreto-Lei n. ${ }^{\circ} 79$, de 4 de Abril de 2006.(in Portuguese)

[5] RSECE - Regulamento dos Sistemas Energéticos de Climatização em Edifícios, Decreto-Lei n. ${ }^{\circ 79}$, de 4 de Abril de 2006.(in Portuguese) 